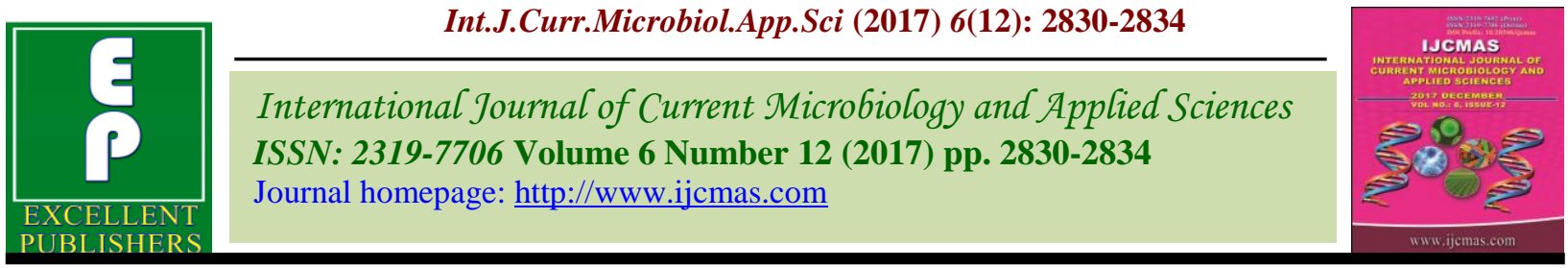

Original Research Article

https://doi.org/10.20546/ijcmas.2017.612.329

\title{
Studies on the Adaptability of Tulip (Tulipa sp.) in Sub-Tropics of West Bengal, India
}

\author{
Srabani Das*, Ayandip Biswas and Tapas Mandal
}

Subject Matter Specialist, SBKVK, Kapgari, Jhargarm, W.B., India

*Corresponding author

A B S T R A C T

\begin{tabular}{|l|}
\hline Ke y w o r d s \\
$\begin{array}{l}\text { Tulip, Flowering, } \\
\text { Yield, Sub-tropics, } \\
\text { West Bengal. }\end{array}$ \\
\hline Article Info \\
\hline $\begin{array}{l}\text { Accepted: } \\
19 \text { October } 2017 \\
\text { Available Online: } \\
10 \text { December } 2017\end{array}$ \\
\hline
\end{tabular}

A field experiment was carried out at Horticulture Research Station, Mandouri, Bidhan Chandra Krishi Viswavidyalaya during 2013-14 and 2014-15 to assess the varietal performance of commercial tulip. Ten varieties viz. Apeldorn, Maureen, Holland Cich, Day Dream, Pussima Design, Avignon, Roi-du-mudu, Clear Water, Pink Diamond and Jumbo Beauty were selected for the research purpose and each variety was considered as one treatment and laid out with Randomized Block Design. The results indicated that maximum plant height $(58.96 \mathrm{~cm})$ and leaf length $(19.04 \mathrm{~cm})$ occurred in Pink Diamond while maximum flower length $(6.06 \mathrm{~cm})$ and flower diameter $(4.35 \mathrm{~cm})$ recorded in Avignon. Pink Diamond showed delayed petal drop in about 3.74 days whereas Roi-dumudu recorded earliest petal drop in about 3.01 days from full bloom. Apeldorn recorder maximum number of stems per plot (16.39) and maximum bulblets (1.61) amongst all selected variety.

\section{Introduction}

The tulip (Tulipa spp.) plays an important role in decorating homes, offices and even shops in this modern era and its importance cannot be denied. The tulip is a bulbous flower having more than 3000 varieties. It originated from Turkey and central Asia, but now Holland is regarded as home of the tulip (Debrowski, 1964). Tulip (Tulipa gesneriana Linn.), the premier ornamental flowering bulb, belongs to family Liliaceae. It is one of the commercially important bulbous ornamental plants owing to its unsurpassed beauty and economic value. It stands at 4th position among the top ten cut flowers in global floriculture trade (Jhon and Neelofer, 2006). Tulip is the major produced flower bulb all over the world. Holland share world tulip production by $60 \% .90 \%$ of the global area planted with flowering bulbs is designed for reproduction of six species - tulip, lily, narcissus, gladiolus, hyacinth and iris (Le Nard and De Hertogh, 2002). Among them, mainly by tulip, which is concentrated in a dozen countries around the world. The largest growing area is in the Netherlands, about $87 \%$ of the global area. Other countries with significant global surface cultivation of tulips are Japan (300 ha), France (293 ha), USA (280 ha) and Poland (200 ha) (Buschmann, 2005). The farms producing flower bulbs use them for two purposes - for further reproduction and for protected cultivation of cut flowers (Wróblewska, 2009). In India tulips are successfully grown mainly under 
the temperate regions of Jammu and Kashmir, Himachal Pradesh and Uttrakhand. Keeping all these in view, this following experiment was undertaken to find out the suitable cultivars for the plains of West Bengal.

\section{Materials and Methods}

The experiment was carried out at the Horticultural Research Station, Bidhan Chandra Krishi Viswavidyalaya, Mondouri, Nadia, West Bengal. The location of the Experimental site at about $23.5^{\circ} \mathrm{N}$ latitude and $89^{\circ}$ E longitude with an average altitude of $9.75 \mathrm{~m}$ above mean sea level. The soil of the field experimental site is new alluvial with good water holding capacity and aeration.

The locality of the experimental site had a humid subtropical climate. The temperature during summer months of April to May range from 36.9 to 38.0 degree $\mathrm{C}$ while the night temperature ranges from 27 to 30 degree $\mathrm{C}$. Winter is mild and short with day temperature varying between 15 to 17 degree $\mathrm{C}$ and night temperature 7 to 10 degree $\mathrm{C}$.

This experiment was laid out with RBD (Randomized Block Design), which was replicated thrice with 10 treatments. Ten varieties of tulip namely Apeldorn $\left(\mathrm{T}_{1}\right)$, Maureen $\left(\mathrm{T}_{2}\right)$, Holland cich $\left(\mathrm{T}_{3}\right)$, Day Dream $\left(\mathrm{T}_{4}\right)$, Pussima Design $\left(\mathrm{T}_{5}\right)$, Avignon $\left(\mathrm{T}_{6}\right)$, Roidu-mudu $\left(\mathrm{T}_{7}\right)$, Clear Water $\left(\mathrm{T}_{8}\right)$, Pink Diamond $\left(\mathrm{T}_{9}\right)$ and Jumbo Beauty $\left(\mathrm{T}_{10}\right)$ were selected for the research purpose and each variety was considered as one treatment. Normal cultural practices were done in the $1 \mathrm{~m}$ $\mathrm{x} 1 \mathrm{~m}$ raised beds with a spacing of $20 \mathrm{~cm} \mathrm{P}-\mathrm{P}$ and $25 \mathrm{~cm} \mathrm{R}-\mathrm{R}$.

\section{Results and Discussion}

The result as well as the relevant discussion of the present research is described in following sub-heads.

\section{Vegetative parameters}

Significant variation in plant height was reflected among the cultivars during the two years (2013-14 and 2014-15) of investigation (Table 1). Plant height ranged from 32.00 to $58.38 \mathrm{~cm}$ in the first year and from 31.09 to $59.53 \mathrm{~cm}$ in the second year.

A maximum of $58.96 \mathrm{~cm}$ plant height was recorded in Pink Diamond $\left(\mathrm{T}_{9}\right)$ followed by Avignon $\left(\mathrm{T}_{6}\right)$ with a plant height of about $50.48 \mathrm{~cm}$ whereas Jumbo Beauty $\left(\mathrm{T}_{10}\right)$ recorded the minimum plant height of 31.82 $\mathrm{cm}$. Leaf length showed a variation of 10.44 to $19.04 \mathrm{~cm}$. Pink Diamond $\left(\mathrm{T}_{9}\right)$ produced leaves with maximum length $(19.04 \mathrm{~cm})$ followed by Avignon $\left(\mathrm{T}_{6}\right)(16.26 \mathrm{~cm})$ and Jumbo Beauty $\left(\mathrm{T}_{10}\right)$ produced leaves with minimum length $(10.44 \mathrm{~cm})$. Leaf width showed a variation of 1.25 to $1.82 \mathrm{~cm}$. Pink Diamond $\left(\mathrm{T}_{9}\right)$ produced leaves with maximum width $(1.82 \mathrm{~cm})$ followed by Avignon $\left(\mathrm{T}_{6}\right)(1.79 \mathrm{~cm})$ and Jumbo Beauty $\left(\mathrm{T}_{10}\right)$ produced leaves with minimum width $(1.25 \mathrm{~cm})$.

\section{Flower quality parameter}

The different cultivars in the study significantly influenced the flower length in both the years of investigation (Table 2). Flower length is an important trait which showed a variation of 3.19 to $6.06 \mathrm{~cm}$. Avignon $\left(\mathrm{T}_{6}\right)$ produced flowers with maximum flower length $(6.06 \mathrm{~cm})$ followed by $\mathrm{T} 1(5.35 \mathrm{~cm})$ and Maureen $\left(\mathrm{T}_{2}\right)$ produced flowers with minimum length (3.19 $\mathrm{cm})$.Flower length ranged from 0.40 to 0.50 $\mathrm{cm}$ in both years. A maximum of $0.48 \mathrm{~cm}$ stem girth was recorded in T4 and Avignon $\left(\mathrm{T}_{6}\right)$ whereas Maureen $\left(\mathrm{T}_{2}\right)$ and $\mathrm{T} 10$ recorded the minimum stem girth of $0.42 \mathrm{~cm}$. Flower diameter ranged from 2.30 to $4.29 \mathrm{~cm}$ in $1^{\text {st }}$ year and 2.34 to 4.41 in the $2^{\text {nd }}$ year of investigation. 
Table.1 Vegetative parameters

\begin{tabular}{|l|c|c|c|c|}
\hline Treatment & Plant height & Leaves per plant & Leaf length & Leaf width \\
\hline $\mathrm{T}_{1}$ & 36.67 & 3.11 & 12.38 & 1.53 \\
\hline $\mathrm{T}_{2}$ & 36.36 & 3.06 & 12.07 & 1.44 \\
\hline $\mathrm{T}_{3}$ & 35.14 & 3.11 & 11.67 & 1.5 \\
\hline $\mathrm{T}_{4}$ & 34.94 & 3.06 & 11.57 & 1.32 \\
\hline $\mathrm{T}_{5}$ & 34.41 & 3.06 & 11.07 & 1.26 \\
\hline $\mathrm{T}_{6}$ & 50.48 & 3.11 & 16.26 & 1.79 \\
\hline $\mathrm{T}_{7}$ & 33.12 & 3.06 & 10.91 & 1.38 \\
\hline $\mathrm{T}_{8}$ & 36.4 & 3.11 & 11.32 & 1.48 \\
\hline $\mathrm{T}_{9}$ & 58.96 & 3.06 & 19.04 & 1.82 \\
\hline $\mathrm{T}_{10}$ & 31.82 & 3.06 & 10.44 & 1.25 \\
\hline S.Em $( \pm)$ & 3.4367 & 0.07962 & 1.04719 & 0.15916 \\
\hline C.D. at 5\% & 7.77436 & 0.18011 & 2.36891 & 0.36005 \\
\hline
\end{tabular}

Table.2 Flower quality parameters

\begin{tabular}{|l|c|c|c|}
\hline Treatment & Flower length & Stem girth & Flower diameter \\
\hline Apeldorn $\left(\mathrm{T}_{1)}\right.$ & 5.35 & 0.45 & 3.58 \\
\hline Maureen $\left(\mathrm{T}_{2}\right)$ & 3.19 & 0.42 & 2.37 \\
\hline Holland cich $\left(\mathrm{T}_{3)}\right.$ & 3.31 & 0.43 & 2.61 \\
\hline Day Dream( $\mathrm{T}_{4)}$ & 3.47 & 0.48 & 2.6 \\
\hline Pussima Design( $\mathrm{T}_{5)}$ & 3.75 & 0.45 & 2.66 \\
\hline Avignon( $\left.\mathrm{T}_{6}\right)$ & 6.06 & 0.48 & 4.35 \\
\hline Roi-du-mudu( $\mathrm{T}_{7)}$ & 3.83 & 0.43 & 2.89 \\
\hline Clear Water $\left(\mathrm{T}_{8)}\right.$ & 3.69 & 0.45 & 2.46 \\
\hline Pink Diamond $\left(\mathrm{T}_{9)}\right.$ & 5.33 & 0.45 & 3.11 \\
\hline Jumbo Beauty $\left(\mathrm{T}_{10)}\right.$ & 3.53 & 0.42 & 2.44 \\
\hline S.Em $( \pm)$ & 0.13741 & 0.02094 & 0.12093 \\
\hline C.D. at 5\% & 0.43961 & 0.04736 & 0.27356 \\
\hline
\end{tabular}

Table.3 Flowering parameters

\begin{tabular}{|l|c|c|c|c|}
\hline Treatment & Planting to FBE & FBE to BB & BB to FB & FB to PD \\
\hline Apeldorn $\left(\mathrm{T}_{1}\right)$ & 45.64 & 4.35 & 2.44 & 3.74 \\
\hline Maureen $\left(\mathrm{T}_{2}\right)$ & 50.46 & 4.09 & 3.01 & 3.25 \\
\hline Holland cich $\left(\mathrm{T}_{3)}\right.$ & 45.88 & 3.82 & 2.8 & 3.58 \\
\hline Day Dream $\left(\mathrm{T}_{4}\right)$ & 46.32 & 4.41 & 2.68 & 3.34 \\
\hline Pussima Design $\left(\mathrm{T}_{5)}\right.$ & 45.84 & 4.41 & 2.54 & 3.4 \\
\hline Avignon $\left(\mathrm{T}_{6)}\right.$ & 64.03 & 4.08 & 2.41 & 3.45 \\
\hline Roi-du-mudu $\left(\mathrm{T}_{7)}\right.$ & 52.11 & 4.06 & 2.53 & 3.01 \\
\hline Clear Water( $\mathrm{T}_{8)}$ & 66.38 & 4.22 & 2.67 & 3.12 \\
\hline Pink Diamond $\left(\mathrm{T}_{9)}\right.$ & 71.41 & 3.92 & 2.85 & 3.74 \\
\hline Jumbo Beauty( $\mathrm{T}_{10}$ & 41.8 & 4.2 & 2.83 & 3.03 \\
\hline S.Em $( \pm)$ & 0.60175 & 0.29596 & 0.1878 & 0.17481 \\
\hline C.D. at 5\% & 1.36126 & 0.6695 & 0.42483 & 0.39545 \\
\hline
\end{tabular}


Table.4 Yield parameters

\begin{tabular}{|l|c|c|}
\hline Treatment & Stems per plot & Bulblets per plant \\
\hline Apeldorn $\left(\mathrm{T}_{1)}\right.$ & 16.39 & 1.61 \\
\hline Maureen $\left(\mathrm{T}_{2}\right)$ & 5.72 & 0 \\
\hline Holland cich $\left(\mathrm{T}_{3)}\right.$ & 5.11 & 0 \\
\hline Day Dream $\left(\mathrm{T}_{4)}\right.$ & 5.17 & 0 \\
\hline Pussima Design( $\mathrm{T}_{5)}$ & 4.33 & 0 \\
\hline Avignon( $\left.\mathrm{T}_{6}\right)$ & 10.44 & 0 \\
\hline Roi-du-mudu $\left(\mathrm{T}_{7)}\right.$ & 4.33 & 0 \\
\hline Clear Water $\left(\mathrm{T}_{8)}\right.$ & 4.33 & 0 \\
\hline Pink Diamond $\left(\mathrm{T}_{9)}\right.$ & 14.44 & 0.72 \\
\hline Jumbo Beauty $\left(\mathrm{T}_{10}\right.$ & 12.61 & 0 \\
\hline S.Em $( \pm)$ & 0.1964 & 0.0778 \\
\hline C.D. at 5\% & 0.44429 & 0.17599 \\
\hline
\end{tabular}

Avignon $\left(T_{6}\right)$ recorded the maximum flower diameter of $4.35 \mathrm{~cm}$ followed by Apeldorn $\left(\mathrm{T}_{1}\right)$ $(3.58 \mathrm{~cm})$ and Maureen $\left(\mathrm{T}_{2}\right)$ recorded the minimum flower diameter of $2.37 \mathrm{~cm}$.

\section{Flowering parameters}

Days required from planting to first flower bud emergence, from first flower bud emergence to bud burst, from bud burst to full bloom and from full bloom to petal drop were recorded as flowering parameters. The different cultivars in the study significantly influenced these different parameters in both the years of investigation (Table 3).

Jumbo Beauty $\left(\mathrm{T}_{10}\right)$ showed earliest flower bud emergence in about 41.80 days followed by Apeldorn $\left(\mathrm{T}_{1}\right)$ (45.64 days) whereas Pink Diamond $\left(\mathrm{T}_{9}\right)$ recorded most delayed flower bud emergence in about 71.41 days from planting. Most early bud burst was recorded in Holland Cich ( $\mathrm{T}_{3}$ ) (3.82 days) followed by Pink Diamond $\left(\mathrm{T}_{9}\right)$ (3.92 days). Day Dream $\left(\mathrm{T}_{4}\right)$ and Pussima Design $\left(\mathrm{T}_{5}\right)$ both showed most delayed bud burst in about 4.41 days from first flower bud emergence. The days taken in this respect was in the range of 2.41 to 3.01 days, the cultivar Maureen $\left(\mathrm{T}_{2}\right)$ took maximum number of days to attain full bloom whereas Avignon $\left(\mathrm{T}_{6}\right)$ came to full bloom early. Apeldorn $\left(\mathrm{T}_{1}\right)$ and Pink Diamond $\left(\mathrm{T}_{9}\right)$ showed delayed petal drop in about 3.74 days followed by Holland Cich $\left(\mathrm{T}_{3}\right)$ (3.58 days) whereas Roi-du-mudu $\left(\mathrm{T}_{7}\right)$ recorded earliest petal drop in about 3.01 days from full bloom.

\section{Yield parameters}

Stems per plot and Bulblets per plant were recorded as the yield parameters. The data on number of stems per plot (Table 4) revealed significant differences during the experiment. The number of stems per plot was in range of 4.33 to 16.39 . It is evident from the results that maximum number of stems per plot (16.39) were produced by Apeldorn $\left(\mathrm{T}_{1}\right)$ followed by Pink Diamond $\left(\mathrm{T}_{9}\right)$ (14.44) whereas Pussima Design $\left(\mathrm{T}_{5}\right)$, Roi-du-mudu $\left(\mathrm{T}_{7}\right)$ and Clear Water $\left(\mathrm{T}_{8}\right)$ recorded as at par as well as they produced minimum number of stems per plot (4.33).

Number of bulblets per plant ranged from 0.00 to 1.77 in first year and from 0.00 to 1.44 in the second investigating year. A maximum of 1.61 numbers of bulblets per plant were recorded in Apeldorn $\left(T_{1}\right)$ followed by Pink Diamond $\left(T_{9}\right)$ with 0.72 number of bulblets per plant whereas other cultivars did not produce any bulblets.

Above study proves that Apeldorn variety gave good responses than other varieties mentioned 
in this research. Apeldorn seems to have comparatively better vegetative, flower quality and flowering as well as yield parameters and hence it can be suggested to be cultivated in the sub-tropics of West Bengal.

\section{Acknowledgement}

The paper is based on the findings of ongoing doctoral research programme carried out at horticulture research station, mandouri, Bidhan Chandra Krishi Viswavidyala (BCKV), Mohanpur Nadia under the scholarship funded by Department of Science and Technology (DST).

Therefore, all authors are thankful to DST and department of floriculture and landscape architecture (BCKV) for encouragement.

\section{References}

Algera, L. (1936). Concerning the influence of temperature on morphological development of the tulip. Proceedings of the Koninklijke Nederlandse Akademie Van Wetenschappen, 39: 846-855.

Banasik, L. and Saniewski, M. (1985). The effect of different auxins on tulip stalk elongation. Acta Horticulturae, 167: 193204.

Boonekamp, P.M. (1997). The role of external factors in growth and development of flower bulbs and bulb flowers: an update since 1992. Acta Horticulturae, 430: 3543.

Boonekamp, P.M., Beijersbergen, J.C.M. and Franssen, J.M. (1990). The development of flowering assays for cold treated tulip bulbs. Acta Horticulturae, 266: 177-181.

Debrowski, J. (1964). Influence of soil moisture on yield of tulip bulb. Acta agrobotanica, 24: 171-204.

Debrowski, J. (1964). Influence of soil moisture on yield of tulip bulb. Acta agrobotanica, 24: 171-204.

Gilford, J.M. and Rees, A.R. (1973). Growth of the tulip shoot. Scientia Horticulturae, 1: 143-156.

Hanks, G.R. and Rees, A.R. (1977). Stem elongation in tulip and narcissus: the influence of floral organs and growth regulators. New Phytologist, 78: 579-591.

Jhon, A.Q. and Neelofar (2006). Tulip, In: Bulbous Ornamental and Aquatic Plants. Advances in Ornamental Horticulture, S.K. Bhattacharjee (Eds). Pointers Publishers, Jaipur-302 003 (Raj.), India. pp. 3:1-72.

Marcinek, B., Hetman, J. and Kozak, D. (2013).Influence of cultivation methods and bulbs planting depth on the growth and yielding of tulips. Actascientiarum polonorum-hortorum cultus, 12(5):97110.

Nard, M.E., Biot, M., Le-Nard, M., Lilien, K.H., Kipis, H. and Haivey, A.H. (1997). Measurement of variation tulip in different conditions. Proceedings of seventh International Symposium on flower bulbs. Herzliya, Israel. Acta Horticulturae, 43: 837-841.

Op den Kelder, P., Benschop, M. and De Hertogh, A.A. (1971). Factors affecting floral stalk elongation of flowering tulips.

Journal of American society of horticultural science, 96: 603-605.

\section{How to cite this article:}

Srabani Das, Ayandip Biswas and Tapas Mandal. 2017. Studies on the Adaptability of Tulip (Tulipa sp.) in Sub-Tropics of West Bengal, India. Int.J.Curr.Microbiol.App.Sci. 6(12): 2830-2834. doi: https://doi.org/10.20546/ijcmas.2017.612.329 